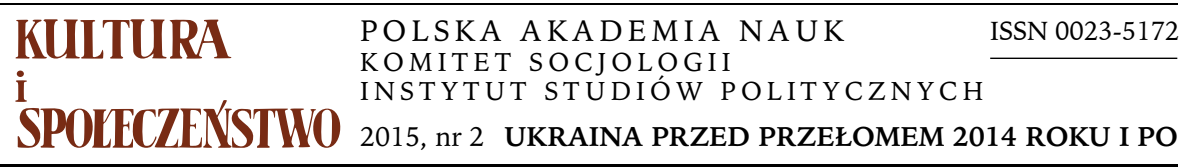

ANDRZEJ SZEPTYCKI

Uniwersytet Warszawski

\title{
POLSKIE MEDIA WOBEC UKRAINY PRZYCZYNEK DO DYSKUSJI
}

Media - owa „czwarta władza” - pełnią ważną rolę we współczesnych państwach demokratycznych, na skrzyżowaniu pomiędzy politykami, społeczeństwem i aktorami gospodarczymi. Są politykom niezbędne, by dotrzeć do wyborców. Stanowią podstawowy kanał komunikacji, za pośrednictwem którego większość obywateli dowiaduje się o wydarzeniach politycznych. Choć podkreślają swą niezależność i autorytet, pozostają zależne od właścicieli i reklamodawców.

Analiza relacji polsko-ukraińskich czy też polityki Polski wobec Ukrainy (i vice versa) nie może zatem pomijać mediów. Niestety, obecny stan badań nad tą problematyką jest - zarówno z perspektywy naukowej, jak i politycznej - niewystarczający. Regularnie prowadzone są badania dotyczące wzajemnej percepcji przez oba społeczeństwa (wystarczy wspomnieć chociażby prace Instytutu Spraw Publicznych - Fomina i in. 2013), ale na temat mediów dysponujemy jedynie ograniczonymi opracowaniami. W miarę całościową próbę analizy tego zagadnienia $\mathrm{w}$ pierwszej połowie lat dziewięćdziesiątych podjęła Agnieszka Sawicz (2010). Istotną część swojej pracy na temat wizerunków imigrantów w Polsce poświęciła Aleksandra Grzymała-Kazłowska (Grzymała-Kazłowska 2007, s. 185-226), analizując prasowe przedstawienia Ukrainy i Ukraińców. Wykazała, że Ukraina jest postrzegana przez pryzmat mitu Kresów, trudnej wspólnej historii, a także współczesnych problemów wewnętrznych i wynikających z nich zagrożeń dla Polski. Bardziej współczesne zagadnienia przedstawione są w publikacji zbiorowej pod redakcją Iwony Hofman i Justyny Maguś (2014). 
Niedostateczne rozpoznanie tej problematyki wynika, jak można sądzić, $z$ trzech zasadniczych powodów. Po pierwsze, analiza mediów jest zjawiskiem mozolnym, wymagającym czasu i/lub nakładów finansowych na ułatwiające prowadzenie takich badań oprogramowanie. Po drugie, rynek medialny ulega dynamicznym zmianom - portale internetowe mają coraz większe ambicje, by być pełnoprawnymi mediami: nie tylko przekaźnikami, ale i producentami informacji. Po trzecie wreszcie, badacze mediów ze względu na charakter swego warsztatu często skupiają się na konkretnym medium i konkretnym zagadnieniu w nim prezentowanym. Przykładem może być wspomniana już publikacja pod redakcją Hofman i Maguś - znajdziemy tam na przykład teksty o relacjach polsko-ukraińskich na łamach regionalnej i lokalnej prasy Wielkopolski czy wizerunku grupy Femen w tekstach portalu TVN 24. Takie cząstkowe analizy nie dają odpowiedzi na najciekawsze, zwłaszcza z perspektywy politycznej, pytanie o ogólny wizerunek (lub w liczbie mnogiej — wizerunki) Ukrainy w polskich mediach.

Tekst ten ma stanowić przyczynek do dyskusji nad problematyką percepcji Ukrainy w polskich mediach, zwłaszcza w okresie Rewolucji Godności i konfliktu zbrojnego z Rosją. Celem moim nie jest całościowa i kompleksowa analiza tej problematyki, ale raczej wstępne zarysowanie obszaru badawczego, sformułowanie hipotez i pożądanych kierunków badań. Przedstawiona analiza dotyczy wybranych stacji telewizyjnych i mediów drukowanych. Na odrębne badania, wykraczające poza ramy tekstu, zasługuje rola mediów internetowych, zarówno tych tradycyjnych, jak i społecznościowych, które od 2013 roku stały się areną szerokiej dyskusji, a niekiedy ostrych sporów na temat polskiej polityki wschodniej. Jako przykład można podać z jednej strony profil na Facebooku „Rosyjska V Kolumna w Polsce” analizujący powiązania polskich polityków, dziennikarzy i działaczy społecznych z Rosją, z drugiej zaś umieszczone również na tym portalu profile „Wileńska” i „Lwowska Republika Ludowa", zachęcające polską mniejszość do przeciwstawienia się władzom litewskim i ukraińskim, a Polskę - do wsparcia tych ruchów.

Jeśli chodzi o telewizję, to dobór próbki badawczej jest relatywnie prosty. Liderami rynku są kanały należące do TVP (26,4\% udziału w rynku) oraz TVN $(18,2 \%)$ i Polsat $(14,6 \%)$ (Reisner 2014, s. 6). Telewizja publiczna w ostatniej dekadzie zajmowała się między innymi Pomarańczową Rewolucją (2004), wyborami parlamentarnymi na Ukrainie (2006), kryzysem politycznym na Ukrainie (2007), stosunkami polsko-ukraińskimi (2008), ukraińsko-rosyjskim kryzysem gazowym (2009), wyborami prezydenckimi na Ukrainie (2010), dwudziestą rocznicą niepodległości Ukrainy (2011), zainteresowaniem w Polsce Kresami Wschodnimi (2012), znaczeniem Euro 2012 (2012), rocznicą zbrodni wołyńskiej (2013). TVN podjęła również takie tematy jak polsko-ukraińskie spory historyczne (2009), polityka sąsiedztwa Unii Europejskiej (2011), korupcja na Ukrainie (2012). Polsat zajmował się stosunkami ukraińsko-rosyjskimi po wyborach prezydenckich w Rosji (2008), groźbą bojkotu Euro 2012 
(2012), rocznicą zbrodni wołyńskiej (2013). Należy odnotować, że TVP jako jedyny $z$ omawianych nadawców emituje dwa programy $w$ istotnym stopniu dotyczące tematyki ukraińskiej. Są to „Telenowyny” - program informacyjny w języku ukraińskim przeznaczony dla mniejszości ukraińskiej w Polsce, przygotowywany przez TVP w ramach jej misji publicznej, oraz „Studio Wschód” prowadzone przez Marię Przełomiec. Obie audycje periodycznie próbowano zdjąć z anteny, co wynikało zarówno ze względów finansowych, jak i prawdopodobnie z dość wyrazistego, antyrosyjskiego charakteru „Studia Wschód” (por. Tyma 2009).

Ten krótki przegląd pozwala na sformułowanie kilku wstępnych tez dotyczących postrzegania Ukrainy w polskich stacjach telewizyjnych. Po pierwsze, główne obszary zainteresowań polskich stacji telewizyjnych $\mathrm{w}$ analizowanym zakresie to przede wszystkim bieżące wydarzenia (wybory, konflikty gazowe $z$ Rosja), stosunki polsko-ukraińskie (historia, bieżące kontakty polityczne, Euro 2012), relacje Ukraina-UE (kwestia umowy stowarzyszeniowej). Okazjonalnie pojawiają się próby analizy wykraczające poza tematykę, którą narzuca kalendarz lub aktualny bieg zdarzeń (historia niepodległej Ukrainy, korupcja na Ukrainie, zwłaszcza na granicy polsko-ukraińskiej).

Po drugie, główne polskie stacje telewizyjne nie prezentują wyrazistego wizerunku Ukrainy. Przykładem może być rocznicowa debata na temat zbrodni wołyńskiej (zatytułowana Na pierwszym planie, 2013) przeprowadzona w lipcu 2013 roku na antenie TVP przez popularnego dziennikarza Piotra Kraśkę. Do dyskusji zaproszono najpierw prezydentów Aleksandra Kwaśniewskiego i Leonida Krawczuka, a następnie dwu przedstawicieli strony ukraińskiej (Andrija Portnowa i Piotra Tymę) i aż czterech przedstawicieli strony polskiej, w tym nieformalnego rzecznika środowisk kresowych księdza Tadeusza Isakowicza-Zaleskiego. Rolę „języczka u wagi” pełnił amerykański historyk zajmujący się dziejami Europy Środkowej i Wschodniej Timothy Snyder. Dyskusja była utrzymana $\mathrm{w}$ tonie roszczeniowym wobec Ukrainy. Ten sam Kraśko podczas krwawych starć na kijowskim Majdanie w lutym 2014 roku nadawał stamtąd specjalne wydanie „Wiadomości”, relacjonując walkę ukraińskiego społeczeństwa z reżimem Janukowycza. Nieco inna jest sytuacja w przypadku stacji o bardziej ograniczonej widowni. Od listopada 2013 roku Ukraińców aktywnie wspierała prawicowa Telewizja Republika. Symbolem tego zaangażowania niejednoznacznie ocenianym przez własne środowisko - stał się korespondent tej stacji w Kijowie Bartłomiej Maślankiewicz, który starał się o komentarz ze strony strzelających do manifestantów członków specjalnej jednostki milicji Berkut (Maślankiewicz 2014). Na drugim krańcu sytuowała się, zwłaszcza od czasu objęcia stanowiska szefa newsroomu przez Wiktora Batera na początku 2015 roku, Superstacja, która zapraszała na antenę nieformalnych rzeczników rosyjskiej polityki, takich jak lider gangu motocyklowego „Nocne Wilki” Aleksander Załdostanow (2015). 
Po trzecie,od listopada 2013 do września 2014 roku obserwujemy znaczący wzrost zainteresowania tematyką ukraińską. Dotyczy to zresztą nie tylko telewizji. Do rozpoczęcia Rewolucji Godności w Kijowie pracowało na stałe dwu korespondentów polskich mediów: Jarosław Junko z PAP i Piotr Pogorzelski z Polskiego Radia. W przeszłości był tam również Roman Kryk, współpracujący z TVP. Sytuacja zasadniczo się zmieniła wraz z wybuchem i eskalacją protestów w Kijowie. 2 grudnia, a zatem bezpośrednio po szczycie w Wilnie i pierwszej próbie rozbicia Majdanu przez ukraińskie władze, TVP i TVN nadały główne serwisy informacyjne („Wiadomości” i „Fakty”) z Kijowa. Polsat zrezygnował wprawdzie $z$ tego rozwiązania, jednak również ta stacja wysłała do stolicy Ukrainy dwie swoje ekipy. Podczas najkrwawszych dni Rewolucji Godności TVP miała na miejscu jedenastu swoich pracowników, nie licząc ekipy programu „Po prostu” i jego autora Tomasza Sekielskiego. TVN wysłała co najmniej pięciu swoich pracowników, TV Republika - troje, w tym wspomnianego już redaktora Maślankiewicza. Nikogo do Kijowa nie wysłał Polsat, który korzystał z materiałów zewnętrznych i współpracował z ukraińskimi dziennikarzami. Do tego należałoby doliczyć reporterów radiowych (Polskie Radio, RMF FM, Tok FM, Radio Zet) i dziennikarzy prasowych (Kucharski 2014). To niespotykane, nawet podczas Pomarańczowej Rewolucji, zainteresowanie Ukrainą trwało właściwie nieprzerwanie do lata 2014 roku. Nie było czymś specyficznym dla polskich mediów, jednak jego skala zaskakiwała. Zainteresowanie znacząco spadło, gdy po letnich sukcesach ukraińskiej „operacji antyterrorystycznej" Rosja skierowała do walki na wschodnią Ukrainę regularne oddziały swojej armii, co skończyło się faktyczną porażką Ukraińców. Od tej pory ukraińska rewolucja i jej następstwa przestały być dla polskich mediów atrakcyjną success story, poza tym telewidzowie byli coraz bardziej zmęczeni tematyką ukraińską.

W przypadku mediów drukowanych istotny problem rodzi dobór tytułów do badań. Nie ma tu kilku widocznych liderów, a analiza czasopism zajmujących pierwsze miejsca w kategorii dzienników i tygodników nie wydaje się interesująca. Najpoczytniejsza gazeta codzienna, wedle danych z sierpnia 2014 roku, to "Fakt”; najpoczytniejszy tygodnik - „Gość Niedzielny”. Pierwszy to tabloid, drugi - czasopismo katolickie. W obu przypadkach może to w istotny sposób wpływać na ich dyskurs na temat wydarzeń na Ukrainie (to wstępne założenie badawcze, nie potwierdzone badaniami). Do analizy wybrano zatem trzy czasopisma: „Gazetę Wyborczą” (druga na liście czasopism codziennych) oraz dwa tygodniki: tygodnik „Do Rzeczy” (piąty w tej kategorii pod względem popularności) i „Przegląd” (ósmy) (Kurdupski 2014a, 2014b). To wybór subiektywny, aczkolwiek aspirujący do pewnej reprezentatywności. Każde z wymienionych pism ma dość wyrazistą linię, jeśli chodzi o Ukrainę. Każde z nich odwołuje się wprost lub pośrednio do innych tradycji historycznych i odzwierciedla (a może współkształtuje) inny dyskurs polityczny obecny we współczesnej polskiej debacie publicznej. 
„Do Rzeczy” czerpie w istotnym stopniu z tradycji Józefa Piłsudskiego zarówno jeśli chodzi o przywiązanie do Kresów Wschodnich, jak i przekonanie o pierwszoplanowym zagrożeniu ze strony ZSRR/Rosji. W odniesieniu do polityki wschodniej czasopismo prezentuje dyskurs Prawa i Sprawiedliwości, zarówno z czasów prezydentury Lecha Kaczyńskiego, jak i obecny. „Przegląd” kontynuuje, choć nie wprost, tradycje narodowej demokracji i realizmu politycznego okresu PRL, co znajduje wyraz przede wszystkim w postulacie poszanowania Rosji jako ważnego sąsiada Polski i gracza na arenie międzynarodowej. Bliski jest dyskursowi Sojuszu Lewicy Demokratycznej — bardziej tego współczesnego niż z czasów prezydentury Aleksandra Kwaśniewskiego. W końcu „Gazeta Wyborcza” kontynuuje tradycje Jerzego Giedroycia. Na płaszczyźnie politycznej w przeszłości najbliżej jej było do Unii Wolności. Obecnie, można przyjąć, iż za partię w stosunkowo największym stopniu realizującą jej wizję Polski redakcja uważa Platformę Obywatelską.

„Gazeta" niemal od początku interesowała się sprawami ukraińskimi. Symboliczny był pod tym względem fakt, że jej twórca i redaktor naczelny Adam Michnik brał udział we wrześniu 1989 roku w zjeździe założycielskim Ludowego Ruchu Ukrainy na rzecz Przebudowy w Kijowie. Wygłosił wówczas pamiętne zdanie: „Niech żyje demokratyczna, wolna i sprawiedliwa Ukraina” (Briuchowiecki 2009, s. 147); nie mówił natomiast jeszcze o niepodległości Ukrainy, ponoć pouczony przed wyjazdem przez Bronisława Geremka o potrzebie zachowania w Kijowie umiaru ze względu na władze w Moskwie. Przez kolejne ćwierć wieku Michnik konsekwentnie angażował się na rzecz pojednania i współpracy między Polską i Ukrainą oraz wsparcia przemian w sąsiednim kraju.

Skupione wokół „Gazety” środowisko miało ważny wkład w dyskusję nad trudną historią polsko-ukraińską i proces pojednania między oboma narodami. Istotną rolę odegrał tu Paweł Smoleński i jego książka Pochówek dla rezuna (2001). Smoleński - pisał w recenzji tej publikacji Jacek Kuroń - opowiedział historie o tym, jak Polacy krzywdzili Ukraińców. Był to obraz skrzywiony, bo przecież było i na odwrót. Można by powiedzieć, że w ten sposób przywracał sprawiedliwość dziejową, bo przecież przez wieki całe głos polskiej skargi brzmiał w Polsce znacznie dobitniej, a w dodatku przez minione pięćdziesiąt lat panowała u nas jednostronna, czarna, antyukraińska propaganda (Kuroń 2001). Stanowisko „Gazety” w kwestii wspólnej przeszłości polsko-ukraińskiej można streścić następująco. Po pierwsze, była to historia trudna; po drugie, wina za taki stan rzeczy leży po obu stronach; po trzecie, potrzebne jest polsko-ukraińskie pojednanie. „Za przelaną krew niewinną na Wołyniu i w Galicji, za niewiarę, przebacz mi, Bracie. [...] Przebacz za głuchotę mojego serca, za skamieniałą duszę moja, za wyschnięte oczy Twoich bliskich. Wesprzyj mnie, Bracie, w bólu mojej pokuty" — pisała w siedemdziesiątą rocznicę zbrodni wołyńskiej „Gazeta” (Borkowski, Szeptycki 2013). 
Z „Gazetą” związani byli lub nadal są znawcy tematyki ukraińskiej, aktywnie działający na różnych płaszczyznach na rzecz współpracy między oboma krajami. Trzeba tu wymienić Mirosława Czecha, członka Związku Ukraińców w Polsce, który jako felietonista „Gazety”, wychodząc poza częste w Polsce schematyczne ujęcie problematyki ukraińskiej, potrafil poprowadzić czytelnika przez meandry polityki wewnętrznej wschodniego sąsiada. Przy tej okazji należy odnotować, że Czech był w swoim czasie sekretarzem generalnym Unii Wolności, co potwierdza tezę o związkach obu środowisk „na kierunku ukraińskim". Kolejną postacią zasługującą na uwagę jest Marcin Wojciechowski, korespondent „Wyborczej” na Bałkanach, a następnie w Moskwie i Kijowie. Wojciechowski z bliska obserwował i komentował ważne wydarzenia z najnowszej historii Ukrainy (Wojciechowski 2006; zob. też Wojciechowski 2008). W 2010 roku za swoją działalność został nagrodzony Nagrodą Pojednania Polsko-Ukraińskiego. Po zakończeniu współpracy z „Gazetą Wyborczą" pracował w Fundacji Solidarności Międzynarodowej, w 2013 roku został rzecznikiem ministra spraw zagranicznych, a w 2015 roku ma powrócić jako ambasador RP do Kijowa. Jego kariera potwierdza, jak się wydaje, tezę o częściowej zbieżności koncepcji międzynarodowych „Gazety” (przynajmniej, jeśli chodzi o kierunek wschodni) z polityką rządzącej od 2007 roku Platformy Obywatelskiej, co znajduje odzwierciedlenie w generalnie pozytywnej ocenie obecnej polityki ukraińskiej Polski na łamach tego czasopisma.

Tygodnik „Do Rzeczy” skupia wielu publicystów centroprawicowych, w przeszłości związanych z „Rzeczpospolitą” i „Uważam Rze”. Czasopismo wykazuje duże, rosnące zainteresowanie Ukrainą, zwłaszcza na fali wydarzeń przełomu roku 2013 i 2014, co zaowocowało — tak jak w przypadku „Gazety” - wejściem tygodnika z tą tematyką również na rynek książkowy (Korniejenko 2014). Oba pisma w szczególności odróżnia fakt, że zainteresowanie tygodnika Ukrainą ma charakter bardziej „gabinetowy” — nie odmawiając jego dziennikarzom kompetencji w kwestiach ukraińskich, trzeba stwierdzić, że nie ma $\mathrm{w}$ tym gronie ludzi, którzy specjalizowaliby się $\mathrm{w}$ tematyce ukraińskiej lub zdobyli „dziennikarskie ostrogi” w tym kraju. Przynajmniej po części wynika to $z$ odmiennego charakteru gazety codziennej i tygodnika opinii.

$\mathrm{Na}$ łamach omawianego tygodnika współistnieją dwa kierunki myślenia o Ukrainie: historyczny, krytyczny wobec Ukrainy z powodu przeszłości i bieżącej polityki historycznej oraz, rzec by można, geopolityczny, przychylny wobec ukraińskiego sąsiada, głównie w kontekście postrzeganego zagrożenia ze strony Rosji. Redakcja dała wyraz tej dwoistości podejścia, publikując w lecie 2014 roku polemikę swoich czołowych publicystów dotyczącą celowości zaangażowania Polski w konflikt w Donbasie. Podczas gdy zwolennicy pierwszego kierunku twierdzili, że Polska nie powinna włączać się w ten konflikt, kierując się wątpliwie rozumianym poczuciem honoru, proponenci drugiego przekonywali, że oba kraje łączy wspólnota interesów strategicznych, a zatem konflikt w Donbasie to „nasza wojna” (Wildstein i in. 2014). 
Kierunek „historyczny” na łamach „Do Rzeczy”, a wcześniej tygodnika „Uważam Rze” reprezentują Rafał Ziemkiewicz i Piotr Zychowicz. W ich interpretacji Polacy byli w przeszłości ofiarami i/lub bohaterami, a współczesne polskie elity chca, by o tym zapomnieli i żyli w poczuciu winy z powodu swojej mało chwalebnej przeszłości. To narodowo-patriotyczna wizja historii, dość archaiczna, sięga dziewiętnastowiecznego podejścia do narracji o przeszłości jako narzędziu konsolidacji narodu. Autorzy kultywują sielankową wizję wschodnich ziem II RP, krytykują Ukraińców przede wszystkim za sympatie wobec UPA, przypominają zbrodnie ukraińskich powstańców na Polakach — nie tylko na Wołyniu, ale i na innych spornych ziemiach polsko-ukraińskich. Z rzadka podejmują takie zagadnienia jak Wielki Głód, czy akcja „Wisła” (Szeptycki 2012).

Reprezentantami drugiej opcji są Piotr Semka, Bronisław Wildstein i Marek Magierowski. Łączy ich przekonanie o zagrożeniu ze strony Rosji, znaczeniu dla Polski konfliktu na Ukrainie, a także krytycyzm wobec polityki Zachodu. Wildstein krytykował na łamach tygodnika zwłaszcza politykę PO, zarzucając tej partii odejście od idei jagiellońskiej. Koncepcja ta, pisał, za polską rację stanu uważała sojusz narodów Europy Środkowo-Wschodniej, które wspólnie stanowiłyby znaczącą siłę regionu i byłyby w stanie przeciwstawić się imperialnym dążeniom Rosji. Została ona odrzucona przez Donalda Tuska i Radosława Sikorskiego, którzy od momentu dojścia do władzy ogłosili, że ich polityka polegać będzie na szukaniu kompromisów z wielkimi mocarstwami, w tym Rosją. "Jagiellońskie mrzonki” zastąpili „piastowskim pragmatyzmem” (Wildstein 2014). Takie zarzuty pod adresem polityki PO często formułowano w pierwszych latach jej rządów, jednak w 2014 roku wydają się one odległe od rzeczywistości. Magierowski negatywnie oceniał politykę UE wobec Rosji, zarzucając europejskim przywódcom brak znajomości historii, a po wybuchu konfliktu zbrojnego także politykę pseudosankcji po aneksji Krymu, w jego przekonaniu prowadzoną tak, „by sama Rosja się o nich nie dowiedziała”. Jego zdaniem, Rosja postrzegana jest na Zachodzie jako ogromny rynek zbytu i przez pryzmat pieniędzy wydawanych tam przez rosyjskich oligarchów. Dlatego istnieje obawa, że Putin podejmie agresywne działania przeciw innym państwom, a UE będzie niezdolna, by na nie zdecydowanie odpowiedzieć (Magierowski 2014).

„Przegląd” najmniej wśród omawianych czasopism uwagi poświęca tematyce ukraińskiej. Nie ma publicystów związanych z tygodnikiem, którzy byliby chociażby we własnej opinii specjalistami od spraw ukraińskich. Tygodnik nie firmował żadnych publikacji książkowych poświęconych tej tematyce. Mimo to jego czołowi publicyści - redaktor naczelny Jerzy Domański, Bronisław Łagowski, Krzysztof Teodor Toeplitz - piszą o Ukrainie, bardzo krytycznie oceniając zarówno to państwo, jak i ukraińską politykę Polski. Ukraina to w ich oczach państwo słabe, „niedokończone”, zamieszkane przez dziesięć milionów Rosjan. Dlatego władze Ukrainy są zmuszone do prowadzenia szeroko zakrojonej ukrainizacji własnego kraju (Łagowski 2008). Ta polityka władz ukraińskich 
budzi istotne zastrzeżenia, zwłaszcza z uwagi na kult Stepana Bandery, odpowiedzialnego za akty terroru przeciwko II Rzeczypospolitej i rzeź wołyńską, która pozostaje nierozliczona. Na Ukrainie nie ma cmentarzy ofiar, w Polsce - pomników. Dawni zbrodniarze zaszczepiają młodemu pokoleniu Ukraińców nacjonalistyczną ideologię, Polska zaś godzi się na to w imię rzekomej racji stanu (Domański 2010). Stawia na współpracę z Ukrainą, choć nie ma pewności czy ta odwzajemni się $\mathrm{w}$ taki sam sposób. $Z$ pewnością natomiast proukraińska polityka prowadzi do pogorszenia relacji z Rosją, co negatywnie odbija się na naszej sytuacji gospodarczej; dzieli nas również z partnerami zachodnimi (Łagowski 2008).

Podsumowując należy stwierdzić, że polskie media postrzegają Ukrainę przez pryzmat, po pierwsze historii, zwłaszcza drugiej wojny światowej (UPA, rzeź wołyńska), po drugie - problemów wewnętrznych, zwłaszcza gdy na Ukrainie dochodzi do zaostrzenia sytuacji politycznej, po trzecie - relacji Ukrainy z Polską, UE i Rosją, po czwarte wreszcie - obecności ukraińskich imigrantów zarobkowych w Polsce. Na tym poziomie analizy sytuacja nie uległa zasadniczej ewolucji od czasów badań prowadzonych przez Aleksandrę Grzymałę-Kazłowską w minionej dekadzie. Wizerunek Ukrainy po części ma charakter zdeformowany, zwłaszcza jeśli chodzi o kwestie historyczne. Polskie media przywiązują do nich nadmierne znaczenie, często przedstawiając ukraińską politykę historyczną w zbyt krytycznych barwach. Między polską prasą i telewizją występują istotne różnice. O ile ta pierwsza w istotny sposób współkształtuje debatę na temat Ukrainy i polskiej polityki wobec tego kraju, o tyle postawa i dyskurs tej drugiej w istotnym stopniu mają charakter relacyjny i reaktywny.

Odnotować należy też pewne zmiany. Obecnie Ukraina jest $\mathrm{w}$ szerszym zakresie obecna $\mathrm{w}$ mediach niż $\mathrm{w}$ przeszłości, choć jest to po części zjawisko czasowe związane $z$ wydarzeniami, jakie zapoczątkowała $w$ listopadzie 2013 roku Rewolucja Godności. Jej wizerunek w polskich mediach stopniowo się poprawia, co współgra ze wzrostem sympatii do Ukraińców w polskim społeczeństwie (14\% w 1995 r., 23\% w 2005 r., 36\% w 2015 r.) (Omyła-Rudzka 2015). Środki masowego przekazu podejmują nowe tematy, wcześniej rzadko omawiane, takie jak sytuacja ukraińskich imigrantów w Polsce - zarówno ich problemy na rynku pracy, jak i stosunek do konfliktu w ojczystym kraju.

Percepcja Ukrainy w polskich mediach jest ważnym i ciekawym zagadnieniem z perspektywy badawczej i politycznej, zwłaszcza od roku 2013, gdy za sprawą kryzysu ukraińskiego polityka wschodnia Polski stała się jednym $\mathrm{z}$ ważnych zagadnień $\mathrm{w}$ debacie publicznej. Zostały tutaj zarysowane jedynie główne tezy dotyczące tej problematyki. Zagadnienie to wymaga bardziej pogłębionych badań, ze szczególnym uwzględnieniem następujących zagadnień. Po pierwsze, należałoby wyodrębnić główne, często rozbieżne, by nie rzec sprzeczne, wizerunki Ukrainy funkcjonujące w polskich mediach. Po drugie, trzeba zdiagnozować współzależności między polskimi środkami maso- 
wego przekazu a uczestnikami życia politycznego i gospodarczo-społecznego; istotne wydaje się zwłaszcza pytanie, która ze stron (dziennikarze czy politycy) w większym stopniu kształtuje dyskurs publiczny w kwestii Ukrainy. Po trzecie, wskazane byłoby zidentyfikowanie związków polskich mediów z ośrodkami zagranicznymi, ze szczególnym uwzględnieniem skali i instrumentów oddziaływania propagandy rosyjskiej w Polsce (Szeptycki 2014). Po czwarte, bardziej szczegółowej analizie należałoby poddać media elektroniczne - zarówno stacje telewizyjne, jak i internetowe, zwłaszcza odgrywające coraz większą rolę media społecznościowe.

\section{BIBLIOGRAFIA}

Borkowski Anton, Szeptycki Andrzej, 2013, Modlitwa za Wotyń, „Gazeta Wyborcza”, 11 lipca.

Briuchowiecki Wiaczesław, 2009, Antysowiecki rusofil, „Nowa Europa Wschodnia”, nr 5.

Domański Jerzy, 2010, Bandera — bohater Juszczenki, „Przegląd”, 7 lutego.

Fomina Joanna i in., 2013, Polska - Ukraina. Polacy - Ukraińcy. Spojrzenie przez granice, Instytut Spraw Publicznych, Warszawa.

Grzymała-Kazłowska Aleksandra, 2007, Konstruowanie „innego”: wizerunki imigrantów w Polsce, Wydawnictwa Uniwersytetu Warszawskiego, Warszawa.

Hofman Iwona, Maguś Justyna (red.), 2014, Obraz wspótczesnej Ukrainy w mediach $w$ Polsce, Wydawnictwo Uniwersytetu Marii Curie-Skłodowskiej, Lublin.

Korniejenko Agnieszka, 2014, Petzająca wojna. Quo vadis Ukraino?, Wydawnictwo m, Kraków.

Kucharski Sebastian, 2014, Polscy dziennikarze nadaja z Kijowa, 21 lutego (http://wyborcza.pl/ 1,76842,15501219,Polscy_dziennikarze_nadaja_z_Kijowa.html).

Kurdupski Michał, 2014a, „Fakt” liderem sprzedaży kioskowej w I pótroczu. Tylko „Parkiet” na plusie, 8 sierpnia (http://www.wirtualnemedia.pl/artykul/fakt-liderem-sprzedazy-kioskowej-w-i-pol roczu-tylko-parkiet-na-plusie\#).

Kurdupski Michał, 2014b, „Do Rzeczy” ostro w dót w I pótroczu. Tylko „Tygodnik Powszechny” na plusie, 21 sierpnia (http://www.wirtualnemedia.pl/artykul/do-rzeczy-ostro-w-dol-w-i-polroczu-tylk o-tygodnik-powszechny-na-plusie).

Kuroń Jacek, 2001, Krew pobratymcza, „Gazeta Wyborcza”, 20 października.

Łagowski Bronisław, 2008, Krótka pamięć, „Przegląd”, 20 kwietnia.

Magierowski Marek, 2014, Von Puttin i zaskoczona Europa, „Do Rzeczy”, 3-9 marca.

Maślankiewicz Bartłomiej, 2014, relacja z Kijowa dla TV Republika 2014, 22 stycznia (http://youtu.be/PmpBD_MoeAw).

Na pierwszym planie, 2013, TVP 1, 10 lipca (http://vod.tvp.pl/audycje/publicystyka/na-pierwszym-p lanie/wideo/10072013/11589080).

Omyła-Rudzka Małgorzata, 2015, Stosunek do innych narodów, „Komunikat z badań CBOS”, nr 14.

Reisner Justyna, 2014, Rynek telewizyjny w II kwartale 2014 roku, Krajowa Rada Radiofonii i Telewizji, Warszawa.

Sawicz Agnieszka, 2010, Problematyka ukraińska w prasie polskiej w latach 1991-1996, Wydawnictwo Poznańskie, Poznań.

Smoleński Paweł, 2001, Pochówek dla rezuna, Wydawnictwo Czarne, Wołowiec.

Szeptycki Andrzej, 2012, „Uważam Rze”. Tendencyjnie pisane, 28 kwietnia (http://www.new.org.pl/ 2012-04-28,tendencyjne_pisanie.html).

Szeptycki Andrzej, 2014, Trolle na informacyjnym froncie wojny krymskiej, 19 kwietnia (http:// kulturaliberalna.pl/2014/04/19/putiniada-trolle-informacyjnym-froncie-wojny-krymskiej). 
Tyma Piotr, 2009, Nowy rodzaj barier, 18 sierpnia (http://www.krytykapolityczna.pl/Wywiady/Tyma Nowyrodzajbarier/menuid-137.html)

Wiadomości, 2014, TVP 1, 20 lutego.

Wildstein Bronisław, 2014, Powrót idei jagiellońskiej, „Do Rzeczy”, 3-9 marca.

Wildstein Bronisław i in., 2014, Czy to jest nasza wojna, „Do Rzeczy”, 1-7 września.

Wojciechowski Marcin, 2006, Pomarańczowy Majdan, Wydawnictwo W.A.B., Warszawa.

Wojciechowski Marcin (red.), 2008, Wotyń 1943-2008. Pojednanie, Biblioteka Gazety Wyborczej, Warszawa.

Załdostanow Aleksander, 2015, wywiad dla Telewizji Superstacja, 14 kwietnia (http://www.super stacja.tv/Wiadomosc,6698/Lider_Nocnych_Wilkow_W_Superstacji_Na_Pewno_Dojdzie_Do_ Prowokacji,1443146/KRAJ,214899).

\section{POLISH MEDIA ON UKRAINE (THE START OF A DISCUSSION)}

\section{Sum mary}

Polish media has played an active role in the policy towards Ukraine, particularly from the outbreak of the Revolution of Dignity and war with Russia, but this subject has not received in-depth academic treatment. The author describes the discourse of Polish mass media on the subject of Ukraine, using selected television stations and newspapers as examples. The most important television stations (TVP, TVN, Polsat) do not present a uniform image of Ukraine, and their discourse is in a large part reactive, in connection with current events. The situation is slightly different in the case of the print media. Three different types of discourse can be distinguished. The weekly Do Rzeczy continues the political tradition of Józef Piłsudski. It displays considerable interest in the former eastern borderlands and is distrustful towards Russia. The weekly Przeglad refers indirectly to the traditions of national democracy and the political realists of the People's Republic of Poland period, being critical of Ukraine and pointing out the importance of relations with Russia. Gazeta Wyborcza has in large measure inherited the ideas of Jerzy Giedroyc. It emphasizes the need for reconciliation with Ukraine and for supporting it in its democratic and pro-European strivings.

\section{Key words/słowa kluczowe}

Polish public opinion on Ukraine / polska opinia publiczna wobec Ukrainy; mass media / środki masowego przekazu; discourse / dyskurs; Revolution of Dignity / Rewolucja Godności; Ukrainian-Russian war / wojna rosyjsko-ukraińska 